\title{
Evaluación clínica y radiográfica de la técnica de distracción osteogénica en la reconstrucción de rebordes alveolares atróficos en la región anterior del maxilar superior
}

\author{
A clinical and radiographic evaluation of the distraction osteogenesis \\ technique for the reconstruction of atrophic alveolar ridges in the anterior \\ region of the upper maxilla
}

\author{
M.E. Allais de Maurette, DDS, MSc, P.E. Maurette O'Brien, DDS, MSc, ${ }^{1}$ R. Mazzonetto, Msc, PhD ${ }^{2}$
}

\begin{abstract}
Resumen: Este estudio tiene como objetivo evaluar clínica y radiográficamente la técnica de distracción osteogénica alveolar en la región anterior del maxilar superior y las posibles complicaciones que pueden aparecer durante el tratamiento. Fueron evaluados 15 pacientes, sometidos a reconstrucción alveolar del maxilar superior en la región anterior con distracción osteogénica, usando un distractor yuxtaóseo. Del total de 15 pacientes encontramos que 13 pacientes $(86,6 \%)$ obtuvieron un éxito total de la técnica, obteniendo una ganancia ósea real media de $7,04 \mathrm{~mm}$; en 1 paciente $(6,66 \%)$ fue parcial $(2,62 \mathrm{~mm})$ y en 1 paciente $(6,66 \%)$ se evidenció un fracaso en la técnica, al alcanzar solo $0,76 \mathrm{~mm}$ debido a problemas en la activación del distractor. En cuanto a las complicaciones surgidas durante el tratamiento fueron divididas en complicaciones menores, toda aqueIla que no interfirió en el éxito del tratamiento, y que estuvieron presentes en 8 pacientes (53,33\%), y complicaciones mayores aquellas que no permitieron la rehabilitación con implantes, y que fue encontrado solo en 1 paciente $(6,66 \%)$. La técnica de distracción osteogénica alveolar, demostró ser eficaz en la reconstrucción de rebordes alveolares atróficos con un éxito de 93,33\%, presentado pequeñas complicaciones que pueden ser solventadas por medio de un seguimiento por parte del profesional.
\end{abstract}

Palabras clave: Distracción ósea alveolar; Implantes Oseointegrados.

Recibido: 24 de agosto 2004

Aceptado: 28 de marzo 2005

1 Odontólogo USM. Caracas -Venezuela. MSc en Cirugía y Traumatología BucoMaxilofacial de la Facultad de Odontología de Piracicaba. Universidad Estadual de Campinas (FOP-Unicamp). Piracicaba-SP-Brasil. Residente del Doctorado en Cirugía y Traumatología Buco-Maxilofacial de la Facultad de Odontología de Pernambuco. Universidad de Pernambuco (FOP-UPE). Recife-PE-Brasil.

2 Odontólogo, Cirujano Buco-Maxilofacial. Profesor Asociado. Área de Cirugía y Traumatología Buco-Maxilofacial y Director del Curso de Especialización en Implantología de la Facultad de Odontología de Piracicaba. Universidad Estadual de Campinas (FOP-Unicamp). Piracicaba-SP-Brasil.

Correspondencia:

Dra. Marvis Allais de Maurette

Rua Luis de Farias Barboza. N 271. ap 50

Boa Viagem- Recife. Pernambuco-Brasil

CEP: 51020110

Email: marvisallais@cirugia-maxilofacial.net
Abstract: This study evaluates clinically and radiographically the distraction osteogenesis technique for the reconstruction of atrophic alveolar ridges in the anterior maxilla region, and the possible complications that arise during treatment. Fifteen patients were evaluated, clinically and radiographically, that had been treated with alveolar distraction osteogenesis in the anterior region, using a juxta-osseous distractor. In 13 patients (86.6\%) the technique was completely successful, there being an effective bone gain of 7,04 $\mathrm{mm}$. In 1 patient (6.66\%) this was partial $(2.62 \mathrm{~mm}$ ) and in 1 patient (6.66\%) the technique failed, as there was a gain of just $0,76 \mathrm{~mm}$ because of problems during the activation. The complications arising during the alveolar distraction osteogenesis were divided into minor complications that did not compromise the success of the technique, and which were found in 8 patients (53.33\%), and major complications that did not permit rehabilitation, which were found in 1 patient (6.66\%). The alveolar distraction osteogenesis technique proved to be an effective technique for the reconstruction of atrophic alveolar ridges with a success rate of $93.33 \%$. There were minor complications but the surgeon intervened in time and these were solved.

Key words: Alveolar distraction osteogenesis, Osseointegrated implants. 


\section{Introducción}

A través del desarrollo del área de la implantología, el establecimiento adecuado del lecho receptor se tornó un requisito fundamental para el éxito del tratamiento con implantes osteointegrados. La cantidad y calidad del reborde alveolar influyen directamente en los resultados biomecánicos y estéticos así como también en la estabilidad de las prótesis implanto soportadas y en la salud de los dientes adyacentes.

En los últimos años los injertos óseos, 1,2 biomateriales, 3,4 y la regeneración ósea guiada,, 6 han sido usadas para alcanzar el aumento de rebordes alveolares. La distracción osteogénica es una técnica de crecimiento óseo gradual que ofrece la posibilidad de promover hueso nuevo de una forma rápida y previsible por medio de los mecanismos naturales de regeneración ósea, preparando el lecho adecuadamente para recibir implantes osteointegrados.

Esta técnica tiene algunas ventajas

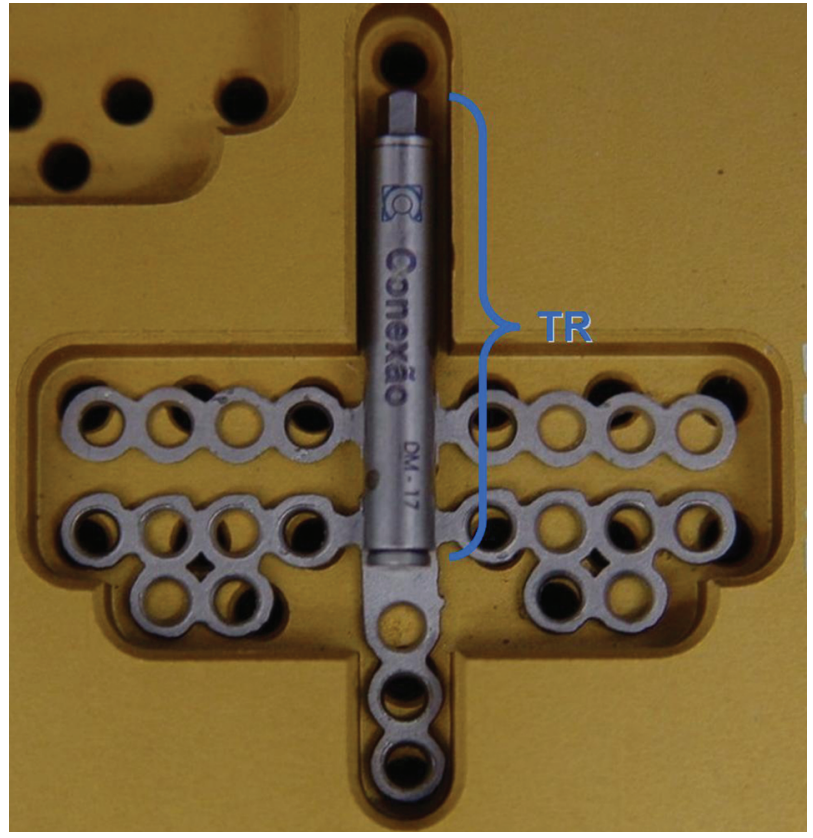

Figura 1. Distractor alveolar yuxtaoseo (Conexión System ${ }^{\circledR}$ SPBrasil) donde puede apreciarse el asta de activación, siendo obtenida la medida en tamaño real. (TR).

Figure 1. Juxta-osseous alveolar distractor (Conexión System, - SPBrazil) showing the activation rod, from which the real size (RS) measurement is obtained. cuando se compara con los injertos

autógenos, tales como: no necesitar de una segunda zona quirúrgica para obtener el injerto, no tiene limite de crecimiento óseo, el crecimiento de tejido blandos, de vasos sanguíneos y nervios van acompañando todo el proceso de crecimiento óseo,, 18 posee una menor tendencia de reabsorción, baja tasa de morbilidad e infección además de permitir una disminución del tiempo para la colocación de los implantes (10 semanas después de la distracción).

El propósito de este estudio fue evaluar clínica y radiograficamente la técnica de distracción osteogénica alveolar en la región anterior del maxilar superior, en 15 pacientes operados en la Facultad de Odontología de Piracicaba-Unicamp entre enero de 2003 a julio de 2004.

\section{Material y método}

Fueron seleccionadas las historias clínicas de 15 pacientes sometidos a cirugía reconstructiva del reborde alveolar antero-superior por medio de distracción osteogénica. En cada uno de los pacientes fueron tomadas una radiografía panorámica a 7 días de posoperatorio antes del inicio de la activación del aparato y otra los 90 días, antes de la retirada del distractor, para evaluar la eficacia del aumento óseo vertical. Para obtener estos valores fue necesario identificar la ganancia ósea real por medio del siguiente protocolo:

A. Determinación del Factor de Ampliación (FA): fue medido el Tamaño Real del Asta de Activación (TR), en el propio aparato (Fig. 1) y el Tamaño de la Imagen del Asta de activación (TI) directamente en la radiografía panorámica (Fig. 2). El FA es aquel

\section{Introduction}

As a result of developments in the area of implantology, the proper establishment of recipient beds became a fundamental requirement for the success of treatment with osseointegrated implants. The amount and quality of the alveolar ridge directly influences biomechanical and aesthetic results as well as the stability of the implantsupported prosthesis and the health of adjacent teeth.

Over the last years bone grafts, 1,2 biomaterials, 3,4 and guided bone regeneration, 5,6 have been used for achieving alveolar ridge augmentation. Distraction osteogenesis is a technique allowing gradual bone growth that makes the formation of new bone possible in a fast and predictable way by means of natural bone regeneration mechanisms, thus preparing the bed suitably before the placement of osteointegrated implants.

This technique has some advantages when compared with autogenous grafts such as: a second surgical site is not required for obtaining a graft, bone growth is not limited, there is a simultaneous expansion of soft tissues, blood vessels and nerves during the complete bone growth process, 18 there is less likelihood of resorption, a lower rate of morbidity and infection, and in addition the time required for placing the implants (10 weeks after distraction) is reduced.

The purpose of this study was to evaluate clinically and radiographically the technique for alveolar distraction osteogenesis in the anterior portion of the upper maxilla, in 15 patients operated on by the Faculty of Dentistry of Piracicaba-Unicamp between January 2003 and July 2004.

\section{Material and Method}

The medical histories of 15 patients that had undergone reconstructive surgery of the anterior portion of the upper alveolar ridge by means of distraction osteogenesis were chosen. A panoramic radiograph was taken of each of the patients seven days into the postoperative period before the activation of the device and another 90 days later, before removal of the device in order to evaluate how effective the vertical bone gain had been. In order to obtain these values it was necessary to identify the real bone gain by means of the following protocol: 
obtenido por la siguiente fórmula: $\mathrm{FA}=\mathrm{TI} / \mathrm{TR}$. Esta variable fue hecha en cada una de las radiografías panorámicas, tanto pre-activación como en las finales.

B. Determinación de la Ganancia Osea Real (GOR): Inicialmente fue obtenido el tamaño de la distracción radiográfica pre-activación (CDR1), en las radiografías de 7 días, por medio de la medida de la distancia entre la porción superior del asta de activación (a) hasta la porción superior del asta de transporte (Fig. 3) (b) multiplicado por el FA obtenido para cada una de las radiografías.

Inmediatamente fue obtenido el tamaño de la distracción radiográfica post-activación (CDR2), por medio de la misma técnica, realizado en las radiografías de 90 días (Fig. 4).

La determinación del GOR se dio por la formula GOR=CDR2- CDR1.

Fueron realizados seguimientos semanales de los pacientes para detección precoz de algún tipo de complicación surgida durante ese periodo. Las complicaciones fueron divididas según el grado de repercusión a la técnica en complicaciones menores, todas aquellas que no comprometieron el resultado de la técnica, tales como edema, dehiscencia, infección y lingualización de disco de transporte, y en complicaciones mayores tales como fractura del disco de transporte o altura inadecuada del aparato.

\section{Resultados}

Fue realizada la evaluación radiográfica de 15 pacientes que se sometieron a cirugía reconstructiva del reborde alveolar antero-superior por medio de distracción osteogénica alveolar usando distractores osteogénicos yuxta-oseos de $9 \mathrm{~mm}$.

Entre los resultados encontramos: 8 pacientes varones, 7 pacientes mujeres, con una edad promedio de 31 años. En 13 pacientes $(86,6 \%)$ el éxito de la técnica fue total, obteniendo una ganancia ósea real media de $7,73 \mathrm{~mm}$; en 1 paciente $(6,66 \%)$ fue parcial $(2,62 \mathrm{~mm})$ ya que el paciente presentó problemas con la activación del aparato sin conseguir la apertura máxima del mismo, pero de igual forma fue comprobada una adecuada altura ósea para rehabilitación con implantes al momento de la extracción del distractor y por último, 1 paciente $(6,66 \%)$ presentó un fracaso en la téc-

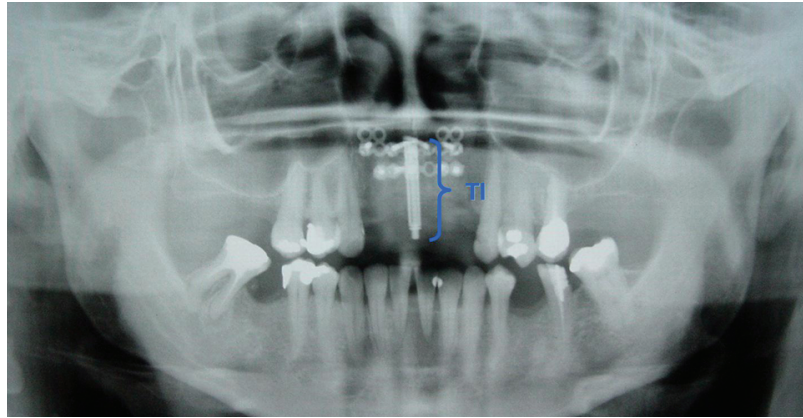

Figura 2. Puede apreciarse el tamaño del asta de activación en la radiografía panorámica $(\mathrm{TI})$.

Figure 2. The size (IS) of the activation rod in the panoramic radiograph can be appreciated.

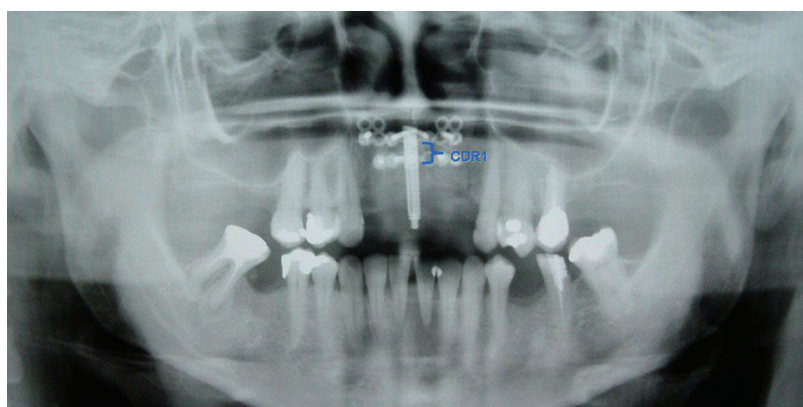

Figura 3. Cantidad de Distracción radiográfica. Preactivación (CDR1).

Figure 3. The radiographic distraction amount. Pre-activation (RDA1).

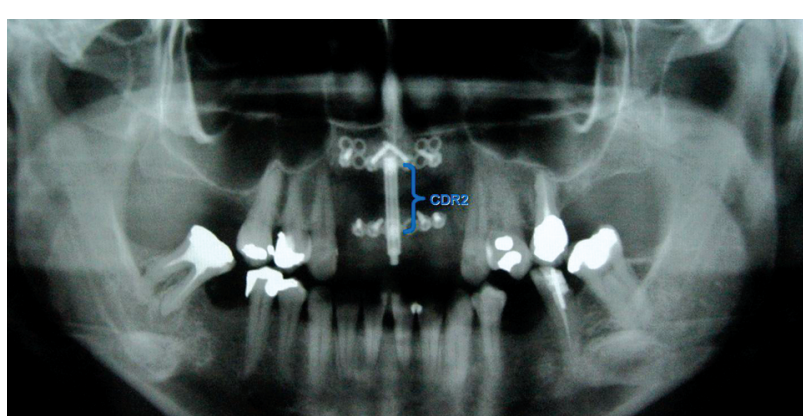

Figura 4. Cantidad de Distracción radiográfica. Postactivación (CDR2).

Figure 4. The radiographic distraction amount. Post-activation (RDA2).
A. Definition of the Amplification Factor (AF): the real size of the activation rod (RS) was measured in the device itself (Fig. 1) and the image size of the activation rod (IS) in the panoramic radiograph itself (Fig. 2). The AF is obtained using the following formula: $A F=I S / R S$. This variable was determined with each of the panoramic radiographs, during the pre-activation stage as well as on completion.

B. Definition of the Real Bone Gain (RBG): Initially this was the radiographical distraction amount (RDA1) pre-distraction that was taken from the radiographs a week later by measuring the distance between the upper portion of the activation rod (a) to the upper portion of the transport rod (Fig. 3) (b) multiplied by the AF obtained in each of the radiographs.

The radiographical distraction amount post-activation (RDA2) was immediately obtained using the same technique with radiographs taken at 90 days (Fig. 4).

The definition of RBG was obtained by the following formula $R B G=$ RDA2-RDA1.

A weekly following of the patients was carried out in order to detect rapidly any complications arising during this period. The complications were divided according to the extent of the repercussions to the technique. Those not adversely affecting the result of the technique, such as edema, dehiscence, infection and lingual displacement of the transport disk were classified as minor problems, and those such as fracture of the transport disk or an inadequate height of the device were classified as major problems.

\section{Results}

Radiographic evaluation was carried out in 15 patients that underwent reconstructive surgery of the anterior por- 
nica, al alcanzar solo $0,76 \mathrm{~mm}$ debido a problemas para activar el aparato (Tabla 1 ).

En cuanto a las complicaciones encontramos que 9 pacientes $(60 \%)$ presentaron algún tipo de complicación, siendo que en 8 de ellos $(88,88 \%)$ la complicación fue menor, teniendo principalmente dehiscencia e infección en 4 pacientes $(35,71 \%$ $\mathrm{c} / \mathrm{u})$, y solo en 1 paciente $(6,66 \%)$ encontramos una complicación mayor debido al trabamiento del aparato (Fig. 5).

\section{Discusión}

La utilización de la técnica de distracción osteogénica para la reconstrucción de rebordes alveolares atróficos, demostró ser un método efectivo que ofrece el incremento de la altura ósea alveolar acompañada del crecimiento de los tejidos blandos adyacentes (93,33\%). Cuando comparamos la distracción osteogénica con otras técnicas quirúrgicas tales como injertos óseos o regeneración guiada, la manipulación de los tejidos blandos se torna difícil cuando la necesidad de ganancia ósea es grande, lo que lleva normalmente a dehiscencias de la herida.

Es importante destacar la predictibilidad de la ganancia ósea, lo que se apunta como otra de las grandes ventajas de esta técnica. Lazar y cols. (1999) ${ }^{14}$ observaron la baja tendencia de reabsorción ósea, que se debe principalmente a la preservación de la nutrición periosteal del segmento osteotomizado.

En relación al tiempo de tratamiento, con la distracción osteogénica, la colocación de los implantes óseos integrados puede ser anticipada, colocándolos 10 semanas después de la primera cirugía.

Es necesario resaltar que a pesar de las ventajas presentadas en esta técnica, existen algunos casos donde está contraindicada su utilización, principalmente cuando se tiene un volumen óseo remanente insuficiente para la realización de la distracción, y en donde exista un alto riesgo de comprometer la base ósea y el disco de transporte, ocurriendo la fractura al momento de la activación del distractor. Para que esto no ocurra, el reborde alveolar a ser distraido, deberá tener una altura mínima de 7 a $8 \mathrm{~mm}$. (Maurette y cols. 2004). ${ }^{15}$

Algunas complicaciones asociadas a la distracción osteogénica pueden ocurrir cuando no es realizado el protocolo quirúrgico pre- tion of the upper alveolar ridge by means of alveolar distraction osteogenesis with $9 \mathrm{~mm}$ juxta-osseous osteogenic distractors.

The results included: 8 male patients, 7 female patients with a mean age of 31 . In 13 patients (86\%) the technique was completely successful, with a average real bone gain of $7.73 \mathrm{~mm}$; in 1 patient (6.66\%) this was partial $(2.62 \mathrm{~mm})$ as the patient had problems in activating the device and the maximum opening was not achieved, but there was enough bone height for implant rehabilitation on removing the distractor, and lastly the technique failed with 1 patient (6.66\%) as only $0.76 \mathrm{~mm}$ was reached due to problems in activating the device (Table 1).

With regard to complications we found that 9 patients (60\%) presented some type of complication. In 8 (88.88\%) the complication was minor, there being mainly dehiscence and infection in 4 patients (35.71\%) and in 1 patient (6.66\%) there was a major complication due to the device blocking (Table 2).

\section{Discussion}

Using the distraction osteogenesis technique for the reconstruction of atrophic alveolar ridges proved to be an effective method that provided an increase in alveolar bone height together with expansion of the adjacent soft tissue (93.33\%). When distraction osteogenesis is compared with other surgical techniques such as bone grafts or guided bone regeneration, dealing with soft tissue becomes difficult when a large amount of bone is required, as this normally leads to dehiscence of the wound.

It is important to stress the predictability of this bone gain, and this should be noted as another of the great advantages of this technique. Lazar et al. (1999)14 observed a low 
conizado o cuando la colaboración del paciente y el seguimiento por parte del profesional no son los correctos, entre las complicaciones más comunes encontramos: edema, dehiscencia, infección, lingualizacion del disco de transporte, complicaciones éstas que no afectan directamente al éxito de la técnica. También podemos encontrar complicaciones mayores que afectaran el tratamiento tales como fractura del hasta del distractor, fractura del disco de transporte (Mazzonetto y Torrezan, 2003). ${ }^{16}$

El paciente debe ser instruido y acompañado por el profesional, durante todo el período de activación, para que en caso de aparecer algún tipo de complicación pueda ser evaluada y tratada de inmediato para no interferir en el éxito de la técnica.

\section{Conclusiones}

Podemos afirmar que esta técnica es un método fiable y predecible para reconstruir rebordes alveolares atróficos, teniendo como resultado una adecuada ganancia ósea con un tiempo menor de tratamiento y con un bajo riesgo de complicaciones.

En regiones estéticas del maxilar superior, la necesidad de asociar técnicas para aumento en espesor es grande. La indicación para asociar la técnica de distracción osteogénica con injertos en bloque es válida, pues con la distracción solo resolvemos de manera previsible los grandes déficits verticales del reborde, pero en algunos casos el aumento de este espesor es necesario, y allí es donde el injerto autógeno pasa a ser el tratamiento ideal. Además, la ganancia de tejidos blandos generada por la distracción se mostró como una de las grandes ventajas estéticas de la técnica, lo que ayuda también en los casos de injertos autógenos para tener un mejor recubrimiento tisular.

\section{Agradecimientos}

Agradecemos al Ministerio de Relaciones Exteriores del Brasil y a la Coordinación de Perfeccionamiento del Nivel Superior (CAPES) por la concesión de las becas de estudio durante el magíster, como parte de Programa de Estudiante Convenio de Postgrado (PEC-PG) la cual hizo posible la realización de este trabajo investigación.

\section{Bibliografía}

1. Artzi Z, Nemcovsky CE. The application of deproteinized bovine bone mineral for ride preservation prior to implantation: Clinical and histological observations in a case report. J Periodontol 1998;69:1062-7. bone resorption rate due mainly to the periosteum of the osteotomized segment receiving nourishment. As a result of the shorter treatment time required for distraction osteogenesis, the placement of osteointegrated implants can be brought forward, and these can be placed 10 weeks after the initial surgery.

It should be stressed that in spite of these advantages, there are some cases where this technique is contraindicated, mainly when the area of remaining bone is insufficient for carrying out distraction, and when there is a high risk of harming the bone base and the transport disk, with a fracture occurring on activating the distractor. For this not to occur, the alveolar ridge that is to be distracted should have a minimum height of 7 to $8 \mathrm{~mm}$. (Maurette et al 2004). ${ }^{15}$

Some complications associated with distraction osteogenesis can occur when the recommended surgical protocol is not carried out, or when patient collaboration or the follow-up by the surgeon is not correct. Among the more common complications we find: edema, dehiscence, infection, lingual displacement of the transport disk that are complications not directly affecting the success of the technique. We can also find major complications that affect treatment such as the fracture of the distraction rod or of the transport disk. (Mazzonetto y Torrezan, 2003). ${ }^{16}$

The patient needs to be instructed and accompanied by the professional during the complete activation period. In the event of any complications, these can be evaluated and treated immediately so that the success of the technique is not affected.

\section{Conclusions}

We can affirm that this technique provides a reliable and predictable method for reconstructing atrophic alveolar ridges and that, as a result, bone augmentation is adequate, and treatment time is shorter while complication rates are low.

In the aesthetic areas of the upper maxilla there is a greater need for associating techniques in order to gain greater width. There are strong indications for associating distraction osteogenesis techniques with block grafts, as with distraction we only resolve in a foreseeable way, large verti- 
2. Betts NJ, Vanarsdall RL, Barber HD, Hibbins-Barber K, Fonseca RJ. Diagnosis and treatment of transverse maxillary deficiency. Int J Adult Orthod Orthognath Surg 1995; 10:75-96.

3. Block MS, Chang A, Crawford C. Mandibular alveolar ride augmentation in the dog using distraction osteogenesis. J Oral Maxillofac Surg 1996;54:309-14.

4. Carls FR, Sailer HF. Seven years clinical experience with mandibular distraction in children. J Craniomaxillofac Surg 1998;26:197-208.

5. Chin $M$, Toth $B$. Distraction osteogenesis in maxillofacial surgery using internal devices: Review of five cases. J Oral Maxillofac Surg 1996;54:45-53.

6. Chin M, Distraction osteogenesis for dental implants. Atlas Oral Maxillofac Surg Clin North Am 1999;7:41-63.

7. Gaggl A, Schultes G, Karcher H. Vertical alveolar ridge distraction with prosthetic treatable distractor: A clinical investigation. Int J Oral Maxillofac Implants 2000;15:701-10.

8. Guerrero CA, Bell WH, Contasti GI, Rodriguez AM. Mandibular Widening by Intraoral distraction osteogenesis. Br J Oral Maxillofac Surg 1997;35:383-92.

9. Horiuchi K, Uchida H, Yamamoto K, Hatano N. Anteroinferior distraction of the atrophic subtotal maxillary alveolus for implant placement: A Case Report. Int J Oral Maxillofac Implants 2002;17:416-23.

10. Ilizarov GA. The principles of the Ilizarov method. Bull Hosp Jt Dis Orthop Inst 1988;48:1-11.

11. Ilizarov GA. The tension-stress effect on the genesis and growth of tissues. Part 1: The influence of stability fixation and soft tissue preservation. Clin Orthop Rel Res 1989:249-81.

12. llizarov GA. The tension-stress effect on the genesis and growth of tissues. Part 2: The influence of the rate and frequency of distraction. Clin Orthop Rel Res 1989:263-85

13. Klen C, Papageorge M, Kovacs A, Carchidi JE. Initial experiences with a new distraction implant system for alveolar ridge augmentation. Mund Kiefer Gesichtschir 1999;3:S74-S78.

14. Lazar F, y cols. Knocherne Regeneration Des Unterrieferalveolarfortsatzes Mit Hilfe Der Vertiralen Rallusdistrartion. Dtsch Zahnarzil Z, v. 54, p. 51-54, 1999.

15. Maurette PE, Allais de Maurette M, Mazzonetto R. Distracción ostetogénica alveolar: una alternativa en la reconstrucción de rebordes alveolares atróficos. Descripción de 10 casos. Rev Esp Cir Oral Maxilofac 2004;26:41-7.

16. Mazzonetto R, Torezan JF. Potencial complications during alveolar distraction osteogenesis. J Oral Maxillofac Surg, Philadelphia, v.61, n.8, p.85. 2003.

17. Polly JW, Figueroa AA. Management of severe maxillary deficiency in childhood and adolescence through distraction osteogenesis with an external, adjustable, rigid distraction device. J Craniofac Surg 1997;8:181-6.

18. Rachmiel A, Srouji S, Peled M. Alveolar ridge augmentation by distraction osteogenesis. Int J Oral Maxillofac Surg 2001;30:510-7.

19. Tavaloki K, Stewart KJ, Michael DP. Distraction osteogenesis in craniofacial surgery: A review. Ann Plast Surg 1998;40:88-99. cal ridge deficiencies. In some cases thickness augmentation is necessary, and this is when the autogenous graft becomes the ideal treatment. In addition, this soft tissue augmentation generated by the distraction has proved to be one the great aesthetic advantages of the technique, also contributing to better tissue covering in autogenous graft cases.

\section{Akonowledgments}

We would like to thank the Foreign Affairs Ministry of Brazil and the "Coordinación de Perfeccionamiento del Nivel Superior» (CAPES) for the study grants during the magister, as part of the program «Estudiante Convenio de Postgrado» (PEC-PG), which enabled carrying out this investigation work. 